Indexed by:

Asinta

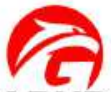

GARUDA

Crossref

crossmark

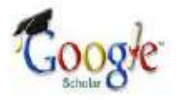

Dimensions

Ongenesearch

\title{
KONSEP PENATAAN LALEBBATA SEBAGAI KAWASAN CAGAR BUDAYA DI KOTA PALOPO
}

\section{Nurhijrah}

Fakultas Teknik Universitas

Andi Djemma, Palopo

Indonesia

Jl. Puang Haji Daud No. 4 Universitas Andi Djemma, Kota Palopo, Indonesia

\section{Liza Utami Marzaman}

Fakultas Teknik Universitas Andi Djemma, Palopo

Indonesia

J1. Puang Haji Daud No. 4 Universitas Andi Djemma, Kota Palopo, Indonesia
Amiruddin Akbar Fisu

Fakultas Teknik Universitas Andi Djemma, Palopo

Indonesia

J1. Puang Haji Daud No. 4 Universitas Andi Djemma, Kota Palopo, Indonesia

\section{Zulham Hafid}

Fakultas Teknik Universitas Andi Djemma, Palopo Indonesia

Jl. Puang Haji Daud No. 4 Universitas Andi Djemma, Kota Palopo, Indonesia

\section{Manuscripts screening} tools:

turnitin $\square$

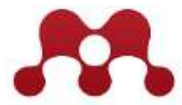

MENDELEY

G grammarly
Key words:

Lalebbata, Palopo, public space, heritage

Doi:

10.17509/jaz.v4i1.30168

Cite article:

Nurhijrah, Fisu, A. A., Marzaman, L. U., dan Hafid, Z. (2021). Konsep Penataan Lalebbata Sebagai Kawasan Cagar Budaya Di Kota Palopo. Jumal Arsitektur Zonasi, 4(1), 62-72. https://doi.org/doi.org/10.17509/jaz.v4i1.30168

Akses online:

untuk naskah lengkap tersedia di: https://ejournal.upi.edu/index.php/jaz/issue/archive 
http://ejournal.upi.edu/index.php/jaz - e-mail: jurnal_zonasi@upi.edu doi.org/10.17509/jaz.v4i1.30168

\section{KONSEP PENATAAN LALEBBATA SEBAGAI KAWASAN CAGAR BUDAYA DI KOTA PALOPO}

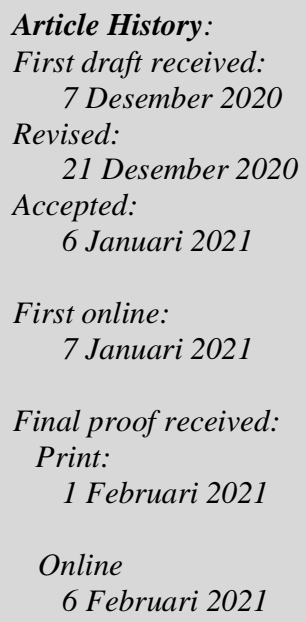

Jurnal Arsitektur ZONASI is indexed and listed in several databases:

SINTA 4 (Arjuna)

GARUDA (Garda Rujukan Digital)

Google Scholar

Dimensions

oneSearch

BASE

\section{Member: \\ Crossref \\ RJI \\ APTARI \\ FJA (Forum Jurna Arsitektur) \\ IAI \\ AJPKM}

\section{Nurhijrah $^{1}$}

Amiruddin Akbar Fisu ${ }^{2}$

Liza Utami Marzaman ${ }^{3}$

Zulham Hafid ${ }^{4}$

1,2, Fakultas Teknik Universitas Andi Djemma, Palopo, Indonesia

${ }^{3}$ RISE Program, Makassar, Indonesia

${ }^{4}$ Palopo Urban Forum, Palopo, Indonesia

Jl. Puang Haji Daud No. 4, Universitas Andi Djemma, Kota Palopo, Indonesia

Email: nurhijrah.rie@gmail.com amiruddinakbarfisu@gmail.com icamarz@gmail.com myzulham@gmail.com

Abstract: In the Palopo spatial structure during the pre-colonial period, Lalebbata area is the center for Palopo City. It is the "middle world" which has a long history and is the place of life for the people of Luwu. Lalebbata is one of the reasons Palopo City is incorporated as a member of the Indonesian Heritage City Network (JKPI) and has been directed by the government as a Heritage City. The value of local wisdom that is held in urban development is the concept of 'marowa' which means crowded or festive. Respect for the Kedatuan Luwu Palace and the Old Jami Mosque are still social norms or values that are believed by the community. Lalebata as one of the historical areas needs efforts to be structured as an effort to revive activities in this area as well as an effort to protect, including controlling the development of the area so as not to lose its historical identity. The Regional Regulation of the City of Palopo on Cultural Heritage mandates that the spatial pattern of the Cultural Conservation Area is stipulated in the Batupasi Sub-Distrct. The management plan for this cultural heritage area includes the revitalization of cultural heritage, as well as the preservation and maintenance of historical buildings as well as being directed as a Trade and Service Allocation Area, particularly as a shopping center and public open space. This paper aims to produce a planning concept and arrangement of the Lalebbata Area in Batupasi as a heritage area as well as a public space in Palopo City. The method used is a participatory approach to residents living around the site, to explore potential and problems, as well as to review policies related to planning and arrangement that will be carried out. The result of this paper is the concept of regional planning by dividing the area into several functions such as commercial space, public and pedestrian space, parks/greean area/sculpture, plaza, exhibition space and museum.

Keywords: Lalebbata, Palopo, public space, heritage

Abstrak: Dalam struktur ruang Palopo pada periode prakolonial, Kawasan Lalebbata adalah sentrum bagi Kota Palopo. Ia adalah 'dunia tengah' yang memiliki sejarah panjang dan menjadi tempat hidup bagi manusia Luwu. Lalebbata menjadi salah satu alasan Kota Palopo tergabung menjadi salah satu anggota JKPI (Jaringan Kota Pusaka indonesia). Nilai kearifan lokal yang dipegang dalam pengembangan kota adalah konsep 'marowa' yang berarti ramai atau meriah. Penghormatan terhadap Istana Datu Luwu dan Masjid Jami Tua masih menjadi norma sosial atau nilai-nilai yang masih diyakini oleh masyarakat. Lalebata sebagai salah satu kawasan bersejarah memerlukan upaya untuk penataan sebagai upaya menghidupkan kembali aktifitas pada kawasan ini sekaligus sebagai upaya perlindungan, termasuk memastikan kawasan ini agar tetap mempertahankan identitasnya sebagai kawasan bersejarah. Peraturan Daerah Kota Palopo tentang Cagar Budaya mengamanahkan perencanaan pola ruang Kawasan Cagar Budaya ditetapkan di Kelurahan Batupasi. Rencana 
pengelolaan kawasan cagar budaya ini meliputi revitalisasi cagar budaya, serta pelestarian dan pemeliharaan bangunan bersejarah serta diarahkan sebagai Kawasan Peruntukan Perdagangan dan Jasa, khususnya sebagai pusat perbelanjaan dan ruang terbuka publik. Tulisan ini bertujuan untuk menghasilkan konsep perencanaan dan penataan Kawasan Lalebbata di Batupasi sebagai kawasan heritage sekaligus sebagai ruang publik yang terletak di Kota Palopo. Metode yang digunakan adalah dengan pendekatan partisipatif kepada warga yang tinggal di sekitar lokasi, untuk menggali potensi dan masalah, serta dilakukan pula tinjauan kebijakan terkait perencanaan dan penataan yang akan dilakukan. Hasil dari tulisan ini adalah konsep penataan kawasan dengan membagi kawasan menjadi beberapa fungsi seperti ruang komersil, ruang publik dan pedestrian, sculpture, plaza, tempat pameran dan museum.

Kata Kunci: Lalebbata, Palopo, ruang publik, heritage

\section{Pendahuluan}

\subsection{Latar Belakang}

Perkembangan kota di Indonesia memiliki sejarah yang berbeda-beda dan merupakan proses yang terus berlangsung hingga saat ini. Kota senantiasa menjadi saksi dari kejadian-kejadian dan situasi yang berlangsung di dalamnya, baik itu situasi ekonomi, sosialbudaya serta lingkungan (Lopez, Marcela., Kuc, 2010). Oleh karena itulah, pengelolaan serta perencanaan kota harus mempertimbangkan aspek ini. Pusaka kota senantiasa akan berkontribusi pada keunikan bentuk kota atau identitas kota itu sendiri. Selain itu, kota juga senantiasa didorong untuk memiliki peran fungsional (Luleva, 2015). Perencanaan kota merupakan instrumen untuk memelihara bentuk dan sekaligus memelihara fungsi pusaka kota (Ramos, 2018). Pengelolaan kawasan cagar budaya merupakan upaya pelestarian pusaka kota yang terpadu dengan pembangunan kota. Permasalahan yang menjadi focus adalah kawasan cagar budaya kita yang semakin hari, semakin menurun kualitasnya baik secara lingkungan, sosial, budaya dan ekonomi. Kawasan cagar budaya di Indonesia tengah mengalami degradasi nilai dan vitalitas fisik akibat ketidakpedulian pengelola dan perencana kota terhadap pelestarian pusaka kota. Jika terus menerus dalam kondisi seperti ini, maka kawasan cagar budaya berpotensi mengalami kepunahan atau ketidakberlanjutan. Dalam rangka mencegah penurunan kualitas lingkungan kawasan pusaka maka diperlukan upaya-upaya pelestarian agar keberlanjutan kawasan cagar budaya tersebut terjamin (Chung, 2009).

Kota Palopo telah terbgabung sebagai salah satu anggota Jaringan Kota Pusaka Indonesia (JKPI). Konsep awal tata ruang dan tata Kota Palopo merupakan proses akulturasi budaya Bugis Luwu dengan identitas agama Islam. Pasca kedatangan VOC, bangunan-bangunan di Kota Palopo kembali kaya dengan gaya arsitektur klasik pada beberapa bangunan. Kota Palopo memiliki kekayaan budaya dan tradisi lokal seperti tarian tradisional, cerita Lagaligo hingga kekayaan kuliner khas Kota Palopo. Kekayaan budaya ini membuktikan bahwa potensi kearifan lokal Kota Palopo dapat menjadi dasar terwujudnya Kota Pusaka Palopo, dalam mendukung pembangunan kota berkelanjutan.

Lalebbata adalah ruang penting dalam perjalanan sejarah Kota Palopo. Pada kawasan ini, denyut nadi perekonomian, sosial-budaya, dan religiusitas warga Palopo bermula. Jalinan ketiga aspek ini disimbolkan oleh keberadaan pasar, Istana kedatuan Luwu dan Masjid Jami Tua Kota Palopo. Signifikansi ruang di kawasan ini kini hanya tinggal pada aras sosial-budaya dan religius semata. Denyut nadi ekonomi semakin hari semakin melemah. Batupasi yang merupakan bagian dari Kawasan Lalebbata mengalami penurunan vitalitas kawasan. Kebijakan pemindahan sentrum ekonomi baru ke Pasar Sentral, membawa serta harapan warga Batupasi atas kehidupan ekonomi yang lebih baik. Lalebata sebagai salah satu kawasan bersejarah memerlukan upaya untuk penataan sebagai upaya menghidupkan kembali aktifitas pada kawasan ini sekaligus sebagai upaya perlindungan, termasuk memastikan kawasan ini agar tetap mempertahankan identitasnya sebagai kawasan bersejarah.

Pemerintah Kota Palopo melalui perda cagar budaya mengamanahkan perencanaan pola ruang Kawasan Cagar Budaya ditetapkan di Kelurahan Batupasi. Rencana pengelolaan kawasan cagar budaya ini meliputi revitalisasi cagar budaya, serta pelestarian dan pemeliharaan bangunan bersejarah. Pada pasal 47 Kelurahan Batupasi juga diarahkan sebagai Kawasan Peruntukan Perdagangan dan Jasa, khususnya sebagai pusat perbelanjaan. Pada pasal 58 Batupasi juga dirahkan sebagai Kawasan peruntukan pertemuan, pameran dan sosial budaya Overlaying ini memperlihatkan bahwa ruang wilayah Kelurahan Batupasi memang diarahkan untuk dimanfaatkan sebagai kawasan yang menarik dan strategis, baik secara secara ekonomi-bisnis, maupun secara sosial-budaya..Penelitian ini bertujuan untuk mengidentifikasi aspek-aspek penting terkait penataan 
ruang, potensi dan masalah yang ada pada Lalebata untuk merumuskan konsep penataan dan pengembangannya sebagai Kawasan heritage.

\subsection{State of The Art}

\section{Kawasan Heritage}

Bangunan cagar budayasangat mengandung nilai kebudayaan yang penting. Ia mempunyai nilai estetika baik dari sisi eksterior ataupun dari sisi interiornya, nilai spiritual dimana ia memiliki posisi penting dalam suatu agama dan kepercayaan tertentu misalnya dalam kasus mesjid ataupun gereja serta kuil di Tibet (Luleva, 2015). Untuk social value, bangunan cagar budaya dapat memberikan hubungan emosional maupun spiritual kepada suatu komunitas masyarakat dan dapat menjadi penanda suatu lokasi. Untuk historical value, bangunan cagar budaya dapat menjadi bukti tentang peradaban suatu masyarakat di suatu tempat (Wahab, Mohdhamdan, Lop, \& Kamar, 2016). Untuk symbolic value, bangunan cagar budaya memberi nilai social atau prestise pada suatu komunitas masyarakat tertentu. Untuk authentic value, bentuk asli bangunan cagar budaya baik dari sisi interior maupun eksterior mewakili ke-khas-an atau keunikan (Kamel-Ahmed, 2015). Semua value tersebut memiliki kontribusi untuk berbagai individu ataupun komunitas masyarakat yang ada. Dewasa ini, tema-tema terkait bangunan cagar budaya atau heritage sebagai bagian dari Kawasan urban sangat banyak diperbincangkan dan diteliti, terutama terkait apa arti keberadaannya, bagaimana urgensinya, keuntungan serta masalah maupun tantangannya.

Arsitektur heritage merupakan sesuatu yang memiliki arti penting dalam perencanaan Kawasan urban atau perkotaan. Hal ini karena; Cagar budaya dapat berperan sebagai penunjang elemen utama urban "decorum" (perilaku beradap yang sangat pantas dan mendorong situasi sosial yang nyaman). Kemudian sebagai penanda peradaban dan histori suatu kota, atau Kawasan, yaitu sebagai berperan sebagai unsur penentu identitas kota. Alasan lainnya adalah untuk menunjang ruang terbuka terpelihara dan direncanakan serta dibangun untuk seluruh komunitas masyarakat dalam rangka menghidupkan berbagai aktifitas masyarakat. Selanjutnya, bangunan cagar budaya dapat dipertahankan, ditransformasi dan diformulasi untuk aktifitas lain sebagai daya Tarik suatu kawasan serta berfungsi secara visual untuk menunjang bidang usaha untuk kegiatan ekonomi kebudayaan (Chung, 2009).

Setiap bangunan di dalam sebuah kota adalah a man made space (ruang karya manusia), yang tergantung dari imagenasi karya sang arsitek berikut ruang dan waktu yang melingkupinya. Arsitektur cagar budaya pada ruang-ruang urban juga merupakan testimoni display material, termasuk teknologi dan gaya konstruksi yang diterapkan (Bal'zannikova, 2014). Setiap kawasan, dengan segala dinamika yang terjadi di dalamnya mewakili secara langsung image evolusi dari penghuninya (Di Pietro Martinelli, Martelli, \& Scannagatta, 2016). Oleh karena itu, bangunan cagar budaya dalam bentuk bangunan visual dianggap lebih baik dan lebih lama bertahan dibandingkan dengan kebudayaan non visual yang ada (Ramos, 2018).

Arsitektur heritage merupakan elemen paling penting dari cultural marker (tetenger kebudayaan) dari suatu identitas sosial. Hal ini menjadi semacam geneologi hidup yang terdapat disekitar kita dengan pengaruh psikologi kebudayaan yang tertanam dan melekat pada suatu generasi, serta mampu mendorong proses pembangunan karakter bagi masyarakat baik secara komunitas maupun individu secara tidak langsung (Oskam \& Karijomedjo, 2015).

\section{Urban Design}

Dalam rangka mengimplementasikan perencanaan kota dibutuhkan kegiatan dan program penataann kawasan (mezo), maka dapat disimpulkan bahwa perancangan kota memiliki peran sebagai penanganan Kawasan berskala mezzo, menjadi salah satu langkah implementasi dalam merancang kota. Perencanaan kota yang terkonsentrasi pada suatu Kawasan dapat berupa: pelestarian kawasan cagar budaya, penataan kembali atau revitalisasi Kawasan bersejarah, pengembangan Kawasan sebagai pusat aktifitas baru, pengembangan kawasan permukiman dan sebagainya. Perancangan kota dapat mengaplikasikan program-program tersebut, sehingga dapat dikembangkan proyek perancangan kota berkaitan dengan pelestarian Kawasan bersejarah, dan sebagainya. Dalam rangka mengimplimentasikan suatu perencanaan kota, para pengambil kebijakan dapat menggunakan instrument atau perangkat pengendali pembangunan ruang kota, seperti: RTRW, RDTR, perijinan lokasi atau guna lahan, zonasi kawasan, peraturan bangunan, pemberian IMB, dan pada kasus kotakota di Amerika terdapat perangkat seperti: zoning, subdivison regulation, dan sebagainya.

Dalam rangka penataan suatu Kawasan dalam lingkup perkotaan, maka perancangan kota hendaknya memiliki nilai dan prinsip yang dianut. Nilai dan prinsip tersebut dapat dijadikan dasar oleh semua orang secara universal (misalnya: keindahan), namun ada pula nilai dan prinsip yang hanya dianut oleh sebagian orang atau kultur tertentu. Nilai dan prinsip ini dapat dikatakan sebagai nilai lokal. Hal ini kemungkinan disebabkan 
karena terjadi pergeseran atau perbedaan cara pandang. Dalam suatu proses perencanaan Kawasan urban, perlu dilakukan langkah-langkah yang dapat dilaksanakan dengan menggunakan metode dan teknik tertentu. Dalam khasanah pengetahuan bidang perancangan kota, telah dikembangkan banyak metode dan teknik untuk mendukung proses perencanaan suatu wilayah dan kota.

\section{Perencanaan Public Space}

Secara umum, public space merupakan ruang terbuka yang dapat mengakomodir kebutuhan akan tempat berkumpul dan aktivitas bersama pada lokasi yang terbuka. Ruang ini memungkinkan terjadinya interaksi antar manusia. Karena pada ruang ini seringkali timbul berbagai kegiatan bersama, maka ruang-ruang terbuka ini dikategorikan sebagai ruang umum. Setiap public space mempunyai nilai lokasi yang didesain, memiliki akses yang terhadap lingkungan sekitarnya, menjadi tempat berinteraksi manusia/pengguna public space dan perilaku masyarakat pengguna ruang publik satu sama lain mengikuti norma-norma yang berlaku setempat (Nóbrega, Maria de Lourdes Carneiro da Cunha., Duarte, 2010). Secara spasial public space diartikan sebagai tempat dimana setiap orang memiliki hak untuk memasukinya tanpa harus membayar sejumlah biaya untuk dapat masuk ke dalamnya.

Public space ditandai oleh tiga hal yaitu responsify ang berarti public space merupakan ruang yang dapat dimanfaatkan untuk berbagai aktifitas dan berbagai kepenting luas, demokratis yang berarti public space dapat dimanfaatkan dan diakses oleh siapa saja, dari latar belakang apapun serta ramah terhadap anak, manula maupun kaum difabel. Yang terakhir adalah bermakna yang berarti bahwa public space idelnya memiliki ikatan, bai kantar sesame manusia, antara manusia dengan ruang, antara manusia dengan lingkungan pada konteks sosial. Ruang publik yang ideal seyogianya memenuhi kriteria berikut: (a) ciri khas dan identitas; (b) atraksi dan destinasi; (c) amenitas; (d). desain yang fleksibel; (e) Seasonal Strategy; dan (f) Aksesibilitas.

Proses perencanaan public space menjadi hal yang penting untuk Kawasan urban secara spasial, hal ini dikarenakan public space merupakan social construction dari ruang ruang yang ada di sekitar masyarakat, baik ruang tempat tinggal maupun ruang yang didatangi ketika sedang melakukan perjalanan, merupakan bagian dari realitas sosial. Perilaku ruang yang ditentukan dan menentukan rlingkungan yang ada di sekitar masyarakat menjadi bagian yang saling terhubung dengan eksistensi sosial kita. Selain itu, public space menciptakan deliniasi. Deliniasi ini yang menjadi batasan spasial sebagai syarat awal dan salah satu syarat utama dalam proses perencanaan dan perancangan kota. Sebagai nodal dan landmark, public space berguna untuk mengarahkan dan sebagai navigasi kota. Jalan dan public space seperti laman menjadi penanda yang akan dimanfaatkan untuk mengidentifikasi dan merencanakan ruang-ruang perkotaan.

Hal lain yang penting adalah membuat parameter bahwa keberhasilan public space dapat dilihat dari ruang yang hidup dan aktif. Hal ini merupakan urgensi dalam proses perencanaan Kawasan urban untuk merencanakan public space yang positif dan bermanfaat untuk masyarakat dan lingkungannya. Selain itu, adanya reintegrasi dari pembagian sosio-spasial merupakan hal yang perlu diperhatikan. Public space menjadi penengah antara ruang privat yang sangat dominan pada wilayah urban dan berperan penting sebagai pembagian sosiospasial. Pergerakan spasial pada Kawasan urban akan menjadi sangat terbatas jika tidak dimediasi. Hal lain adalah adanya konektifitas kota terhadap zonasi-zonasi ruang perkotaan. Meluasnya Kawasan urban pada suatu wilayah menjadi penyebab spesialisasi ruang, dimana terjadi dikotomi yang bersifat simbolis dan fungsional yang terjadi baik pada lingkungan publik maupun pada ruang privat. Teknologi transportasi telah memungkinkan kita untuk dapat tinggal dan bekerja di luar kota serta pusat perkotaan dapat menekan density atau kepadatan penduduknya. Kemampuan masyarakat ntuk dapat mengakses seluruh ruang perkotaan telah mendegradasi interaksi antara penduduk kota dan lingkungan terbangunnya, seperti yang telah berlangsung sepanjang sejarah.

\subsection{Tujuan Penelitian}

Tujuan penelitian dan penulisan ini adalah untuk menghasilkan suatu konsep penataan dan perencanaan Kawasan Lalebbata sebagai Kawasan heritage di Kota Palopo, yang sesuai atau tidak bertentangan dengan arahan kebijakan pemerintah daerah Kota Palopo dan kebutuhan masyarakat yang tinggal pada Kawasan tersebut. Selain itu diharapkan konsep tersebut dapat menjadi masukan untuk pemerintah dalam rangka menghidupkan kembali Kawasan Lalebbata yang memiliki histori dan sejarah panjang sekaligus sebagai bagian dari Kota Pusaka.

\section{Metode Penelitian}

Konsep perencanaan Kawasan Lalebbata dibuat berdasarkan analisis dan tinjauan, baik tinjauan makro, tinjauan kawasan maupun tinjauan kebijakan. Pengumpulan data dilakukan dengan pendekatan partisipatif kepada masyarakat yang tinggal dan melakukan usaha di sekitar lokasi. Pendekatan partisipati ini dilakukan 
baik dalam proses pemetaan, identifikasi potensi dan masalah, hingga proses perencanaan. Pendekatan ini memprioritaskan pemahaman warga terhadap potensi dan permasalahan yang ada, sehingga wargalah yang seharusnya diberikan kepercayaan atau terlibat dalam memaksimalkan potensi serta menyelesaikan masalah yang ada mulai dari proses identifikasian masalah; menilai dan memformulasikan solusi dari permasalahannya, baik fisik, sosial, ekonomi, maupun budaya dan kesehatan lingkungan, sampai pada pembangunan visi dan aspirasi, dan kemudian memprioritaskan, mengintervensi, merencana, mengelola, memonitor, dan bahkan dalam hal pemilihan teknologi yang mereka anggap paling tepat untuk diterapkan (Fisu \& Marzaman, 2018).

Perencanaan partisipatif berawal dari keyakinan bahwa keberhasilan program-program pembangunan ditentukan oleh komitmen semua stakeholders dan komitmen ini didapat sejauh mana mereka terlibat dalam proses perencanaan program tersebut (Sari, 2016).

\section{Hasil dan Pembahasan}

\subsection{Tinjauan Makro}

Lalebbata adalah ruang penting dalam perjalanan sejarah Kota Palopo. Pada kawasan ini, denyut nadi perekonomian, sosial-budaya, dan religiusitas warga Palopo bermula. Jalinan ketiga aspek ini disimbolkan oleh keberadaan pasar, Istana Datu Luwu dan Masjid Tua Jami' Kota Palopo. Signifikansi ruang di kawasan ini kini hanya tinggal pada aras sosial-budaya dan religius semata. Denyut nadi ekonomi semakin hari semakin melemah. Batupasi mengalami penurunan vitalitas kawasan. Kebijakan pemindahan sentrum ekonomi baru ke Pasar Sentral, membawa serta harapan warga Batupasi atas kehidupan ekonomi yang lebih baik. Lalebata sebagai salah satu kawasan bersejarah memerlukan upaya untuk penataan sebagai upaya menghidupkan kembali aktifitas pada kawasan ini sekaligus sebagai upaya perlindungan, termasuk memastikan kawasan ini agar tetap mempertahankan identitasnya sebagai kawasan bersejarah. .

Secara makro, Kawasan Lalebata berada pada Kawasan perkotaan Palopo, terletak di Kelurahan batupasi. Kawasan ini terintegrasi dengan pusat pemerintahan Kota Palopo melalui jaringan jalan utama, juga terkoneksi dengan pusat bisnis dan perdagangan Kota Palopo.

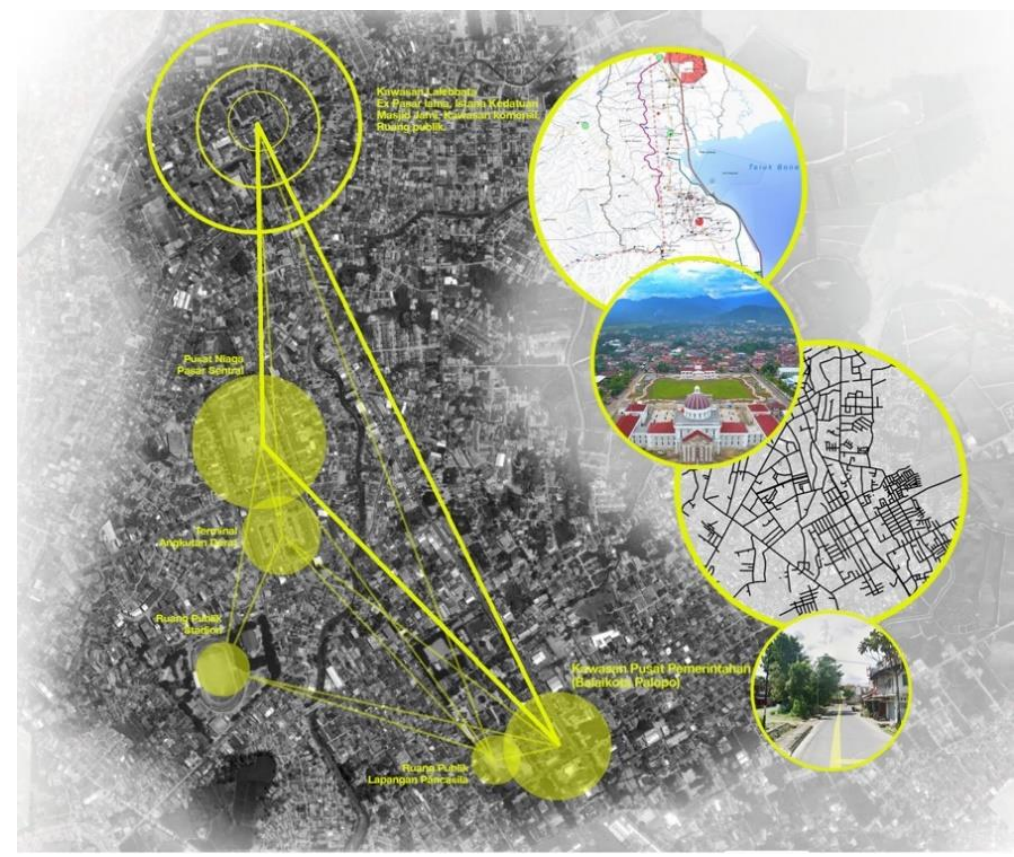

Gambar 1. Interaksi Kawasan Lalebata dengan Pusat Pemerintahan, Pusat Perekonomian dan ruang-ruang publik.

Sumber: analisis 2020

\subsection{Tinjauan Kawasan}

Terkonsentrasinya bangunan cagar budaya yang intens pada kawasan Lalebbata ini serta histori kawasan ini. Menjadi alas an kuat mengapa Lalebbata menjadi sentrum wilayah dalam penataan Palopo sebagai kota pusaka. Karakteristik wilayahnya yang memiliki ciri khas arsitektur pra-kolonial yang berada di tengah pemukiman kota moderen saat ini. Hal ini pula menjadi tantangan tersendiri, melihat beberapa 
bangunan yang tumbuh saat ini, seperti Hotel Platinum dengan desain modern, tampaknya tidak sejalan dengan rasa tempat (sense of place) yang telah ada sebelumnya, seperti gaya artdeco yang ditampilkan di Istana kKdatuan Luwu dan gaya arsitektur Luwu sebagaimana dalam desain bangunan Masjid Jami Tua dan Rumah Adat.

Kawasan ini dilintasi oleh beberapa jalan-jalan utama antara lain Jl. Andi Djemma yang merupakan terusan dariJl. Jendral Sudirman (Jalan Protokol di Kota Palopo), Selain itu terdapat Jl. Ahmad Yani yang juga melintasi Istana Kedatuan Luwu. Kedua ruas jalan ini memiliki mobilitas yang cukup tinggi untuk kawasan urban Kota Palopo. Orang-orang dan kendaraanyang melintasi jalan-jalan ini memiliki motivasi perjalanan yang beragam. Selain itu juga terdapat Jl. landau yang juga cukup sibuk pada kawasan ini. Selain Istana Kedatuan Luwu, pada kawasan ini terdapat berbagai tempat dengan fungsi dan aktifitas yang berbeda-beda. Di sekitar site ex Pasar Lama banyak bangunan yang berfungsi sebagai bangunan komersil milik warga, antara lain warung kopi, bengkel, took peralatan, laundry, warung makan, dan lain-lain. Selain itu terdapat pula sekolah dasar, sarana peribadatan yaitu Masjid Jami' Tua, Sisanya merupakan bangunan-bangunan milik masyarakat yang berfungsi sebagai permukiman atau rumah tinggal. Dengan banyaknya aktifitas pada kawasan ini, sehingga terjadi pula interaksi antar aktifitas tersebut. Intensitas yang paling tinggi adalah interaksi antara aktifitas permukiman dan aktifitas peribadatan, yaitu Masjid Jami' Tua. Karakter masyarakat Kota Palopo yang religious membuat aktifitas di Masjid jami' tidak pernah sepi saat tiba waktu sholat. Orangorang yang beraktifitas bukan hanya mereka yang tinggal di dalam kawasan ini, namun juga masyarakat yang berada di luar kawasan ini. Selain itu terjadi pula interaksi antara permukiman dan sekolah, serta kawasan ruko.

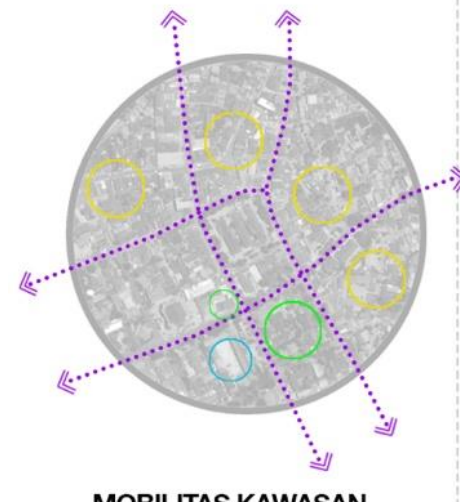

MOBILITAS KAWASAN

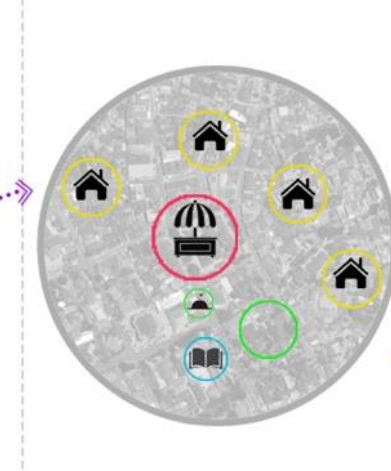

AKTIFITAS KAWASAN

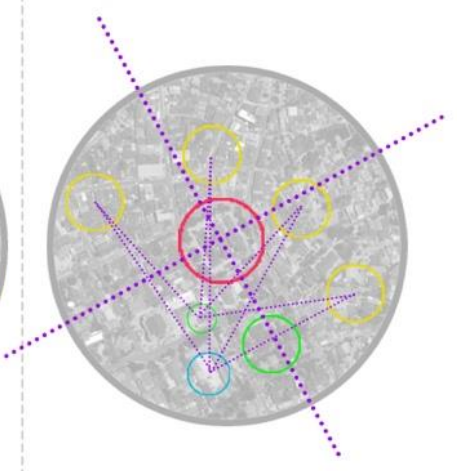

INTERAKSI KAWASAN

Gambar 2: Ilustrasi Mobilitas, Aktifitas dan Interaksi Kawasan Lalebata Sumber: analisis 2020

\subsection{Tinjauan Kebijakan}

Pelaksanaan P3KP (Program Penataan dan Pelestarian Kota Pusaka) merupakan upaya pemerintah yang bertujuan mengawal dan melindungi Kota Pusaka yang ada dan tersebar di seluruh penjuru Indonesia. Terdapat 47 kabupaten dan kota di Indonesia yang menjadi member Jaringan Kota Pusaka Indonesia (JKPI) sebagai kota pusaka. Sejumlah anggota JKPI ini akan mendapat perhatian besar dengan upaya strategis melalui pendekatan entitas sosio-spasial kota untuk membantu penataan ruang kota berbasis pengelolaan keragaman pusaka. Kota Palopo yang terletak di Propinsi Sulawesi Selatan merupakan salah satu anggota JKPI tersebut dan telah diarahkan oleh pemerintah sebagai Kota Pusaka.

Peraturan Daerah (Perda) Kota Palopo Nomor 9 Tahun 2012 pasal 37 mengamanahkan perencanaan pola ruang Kawasan Cagar Budaya ditetapkan di Kelurahan Batupasi. Rencana pengelolaan kawasan cagar budaya ini meliputi revitalisasi cagar budaya, serta pelestarian dan pemeliharaan bangunan bersejarah. Pada pasal 47 Kelurahan Batupasi juga diarahkan sebagai Kawasan Peruntukan Perdagangan dan Jasa, khususnya sebagai pusat perbelanjaan. Pada pasal 58 Batupasi juga dirahkan sebagai Kawasan peruntukan pertemuan, pameran dan sosial budaya. Sementara itu, dilihat dari struktur ruang, Batupasi masuk sebagai pusat lingkungan permukiman (I-IV/C/1) di Kecamatan Wara Utara. Overlaying ini memperlihatkan bahwa ruang wilayah Kelurahan Batupasi memang diarahkan untuk dimanfaatkan sebagai kawasan yang menarik dan strategis, baik secara secara ekonomi-bisnis, maupun secara sosial-budaya.

Pemerintah Kota Palopo dalam perencanaan kawasan Lalebbata juga telah mengesahkan Peraturan Wali Kota (Perwal) Nomor 62 Tahun 2016 tentang Rencana Tata Bangunan dan Lingkungan (RTBL) Kawasan Pusat Niaga Kota Palopo. Dalam RTBL ini, Batupasi terdelineasi pada 3 blok dari 8 blok yang direncanakan, yakni: 
a. Blok A adalah pusat pemerintahan lalebbata, dengan kerangka kawasan pada koridor Andi Djemma;

b. Blok B adalah kawasan campuran (mix use) dengan kerangka kawasan pada koridor Andi Dejmma, Landau dan Jalan Poros-Masamba;

c. Blok $\mathrm{C}$ adalah permukiman tradisional dan permukiman penduduk dengan kerangka kawasan pada koridor Landau, Opu To Sappaile dan Haji Hasan.

Sementara itu, dalam rangka perlindungan dan pengelolaan cagar budaya di wilayah Batupasi dan Kota Palopo secara umum, Wali Kota Palopo juga telah mengesahkan Peraturan Daerah (Perda) Nomor 8 Tahun 2014 tentang Pelestarian dan Pengelolaan Cagar Budaya Kota Palopo. Tiga bangunan cagar budaya sesuai Perda di atas yang berada di kawasan Lalebbata adalah Masjid Jami Tua, Istana Datu Luwu, serta Kantor Pos dan Giro.

Dalam Rencana Pembangunan jangka Menengah daerah (RPJMD) Kota Palopo juga disebutkan, bahwa rencana struktur ruang Kota Palopo diarahkan untuk pengembangan jaringan pejalan kaki dan penataan jalur pejalan kaki serta penyediaan ruang terbuka hijau (RTH) public sebesar 20,41\%. Selain itu, Kelurahan Batupasi juga diarahkan sebagai Kawasan strategis kota (KSK) yang disebut sebagai kawasan menara paying Luwu yang terintegrasi dengan pusat kuliner dan oleh-oleh seluas 1 ha. Hal ini juga diintegrasikan dengan KSK bersejarah Istana Datu Luwu dan Masjid Djami Tua seluas 2 ha di Kelurahan Ammasangan yang sekaligus diarahkan sebagai Kawasan Peruntukan Pariwisata Budaya.Di dalam RPJMD pula disebutkan bahwa Kelurahan Batupasi diarahkan dan dikembangkan sebagai Kawasan periwisata buatan, yaitu rencana pengembangan wisata kuliner. Pada Kawasan peruntukan Ruang terbuka Non Hijau (RTNH), direncanakan plaza sebagai tempat berinteraksi warga dengan berbagai aktifitas seperti sosialisasi, menikmati suasana kota, bercengkrama bersama keluarga dan kerabat, dan lain-lain, sekaligus ditetapkan sebagai Kawsan Peruntukan Pertemuan, Pameran dan Sosial Budaya. Rencana struktur ruang dilakukan melalui strategi penyebaran pusatpusat pelayanan skala kota dengan mengendalikan intensitas pemanfaatan ruang secara horizontal di kawasan pusat kota. Strategi peningkatan daya saing kota melalui program inovasi yang berkearifan lokal, salahsatunya dengan merevitalisasi Kawasan bersejarah dengan perwujudan pengembangan kota pusaka dengan pemanfaatan teknologi dan memperhatikan ruang publik.

\subsection{Analisis dan Konsep Perencanaan}

Sebelum melakukan analisis dan identifikasi kebutuhan fasilitas warga dan diintegrasikan dengan konsepsi Kawasan heritage terlebih dahulu dilakukan pemetaan masalah secara partisipatif dengan warga yang tinggal di sekitar Kawasan Lalebbata. Kegiatan ini bertujuan untuk menemukenali masalah-masalah yang dihadapi warga Batupasi terkait sosial, budaya, ekonomi dan kawasan yang didiami. Pada sesi ini, warga diajak berdiskusi mengenai masalah dan kendala-kendala yang dihadapi dalam mewujudkan kawasan pusaka yang terintegrasi. Masalah-masalah ini kemudian dituliskan dan dipetakan untuk mencari akar permasalahan yang menjadi sebab terjadinya masalah tersebut. Selain itu, diidentifikasi pula dampak yang ditimbulkan dari masalah tersebut.

Selanjutnya, warga diajak untuk menunjukkan lokasi permasalahan yang telah disebutkan sebelumnya di atas peta wilayah Batupasi. Selain itu, warga juga diajak menunjukkan elemen-elemen lain dari peta yang penting sepeti jalan-jalan utama hingga lorong-lorong, bangunan atau tempat bersejarah, termasuk fasilitas publik seperti pasar, taman, sekolah, jalur transportasi, rumah ibadah, lokasi tempat bekerja, fasilitas kesehatan dan sebagainya. Dalam sesi ini, warga diajak pula menunjukkan tempat-tempat yang menurut mereka menyenangkan, keren, tenang dan mempunyai pemandangan yang bagus. Aktivitas ini menggunakan peta sebagai alat utama.

Tabel 1: Identifikasi masalah dengan metode partisipatif

\begin{tabular}{clll} 
No. & \multicolumn{1}{c}{ Akar Masalah } & \multicolumn{1}{c}{ Masalah } & \multicolumn{1}{c}{ Dampak } \\
1 & $\begin{array}{l}\text { Pemindahan pusat kegiatan } \\
\text { ekonomi ke Pasar Sentral/Pusat } \\
\text { Niaga Palopo ke Dangerakko- } \\
\text { Amassangan }\end{array}$ & $\begin{array}{l}\text { Kegiatan bisnis-ekonomi di dalam } \\
\text { kawasan mengalami kelesuan. }\end{array}$ & $\begin{array}{l}\text { Banyak warga yang pindah } \\
\text { domisili dan memindahkan usaha } \\
\text { ke Dangerakko-Amassangan }\end{array}$ \\
\hline 2 & $\begin{array}{l}\text { Tidak ada tempat bermain anak } \\
\text { dan tempat bertemu warga lanjut } \\
\text { usia (lansia) }\end{array}$ & $\begin{array}{l}\text { Anak-anak bermain di jalanan, } \\
\text { warga berinteraksi di pinggir } \\
\text { jalan }\end{array}$ & $\begin{array}{l}\text { Membahayakan kesehatan dan } \\
\text { keselamatan jiwa anak-anak dan } \\
\text { warga lansia }\end{array}$ \\
\hline 3 & $\begin{array}{l}\text { Perubahan kebijakan manajemen } \\
\text { lalu lintas oleh Pemerintah Kota } \\
\text { Palopo }\end{array}$ & $\begin{array}{l}\text { Tidak ada trayek angkutan umum } \\
\text { yang melintasi Batupasi }\end{array}$ & $\begin{array}{l}\text { Mobilitas penduduk tidak } \\
\text { terlayani oleh angkutan } \\
\text { massal/angkutan umum }\end{array}$ \\
\hline
\end{tabular}




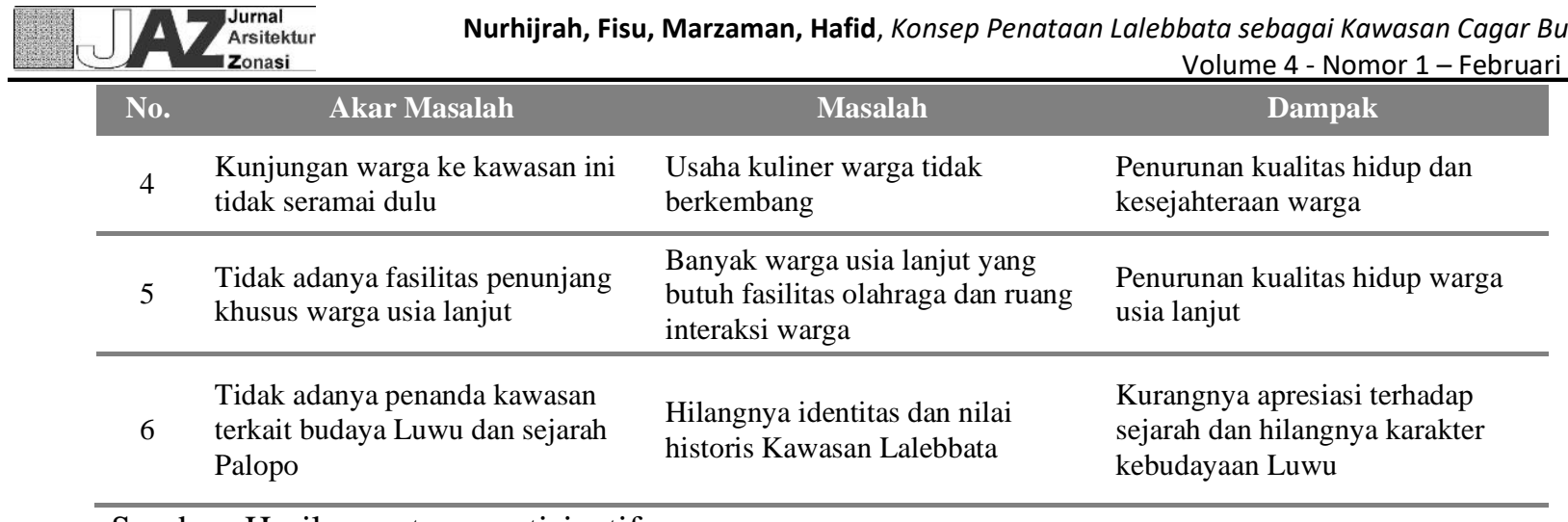

Sumber: Hasil pemetaan partisipatif

Diskusi yang yang hadir dalam proses pemetaan partisipatif dapat dikategorikan dalam 6 topik utama, antara lain: ruang terbuka publik; mobilitas dan walkability; sejarah, seni dan budaya; olahraga, kesehatan dan pariwisata; akses perempuan, anak-anak dan lansia; bisnis dan ekonomi. Topik-topik di atas dianalisis terkait tujuan yang ingin dicapai. Dari sini, laporan ini mengeluarkan arahan program/kegiatan yang dapat dipedomani terkait pengembangan kawasan tersebut.

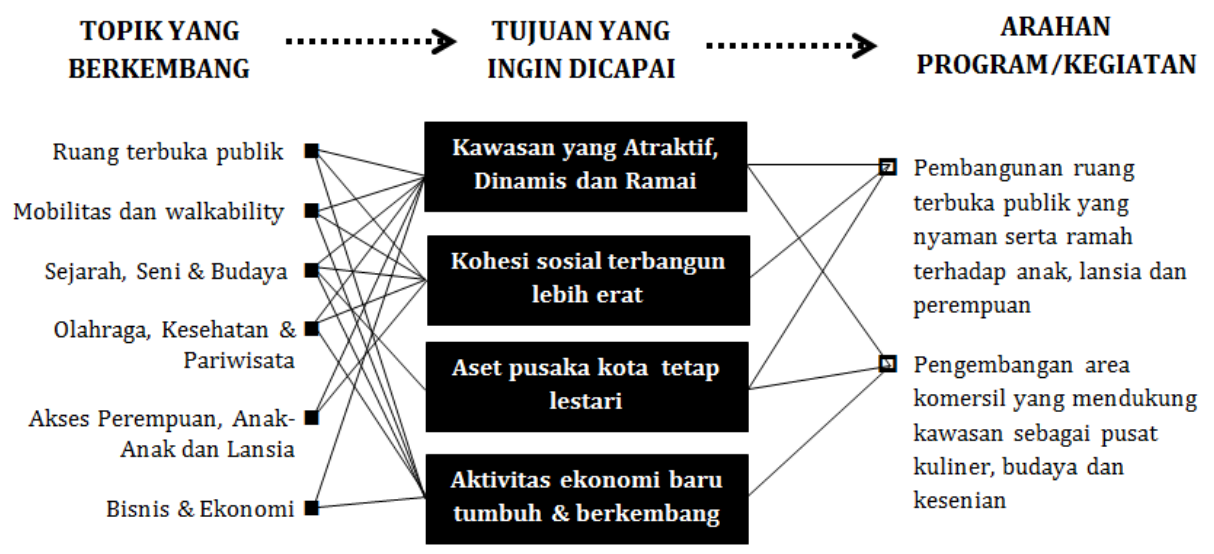

\section{Gambar 3: Arahan pengembangan Kawasan Lalebbata \\ Sumber: analisis 2020}

Pada site ini akan direncanakan ruang publik yang mampu mengakomodir berbagai aktifitas, antara lain plaza sebagai entry point dari perencanaan yang akan dilakukan, jalur pedestrian, pusat kuliner, dan pusat oleh-oleh. Aktifitas yang dominan dilakukan oleh masyarakat di ruang-ruang publik adalah adalah aktifitas yang bersifat restorative seperti berkumpul, makan, berjalan-jalan, dan lain-lain (Nurhijrah \& Kusuma, 2014).

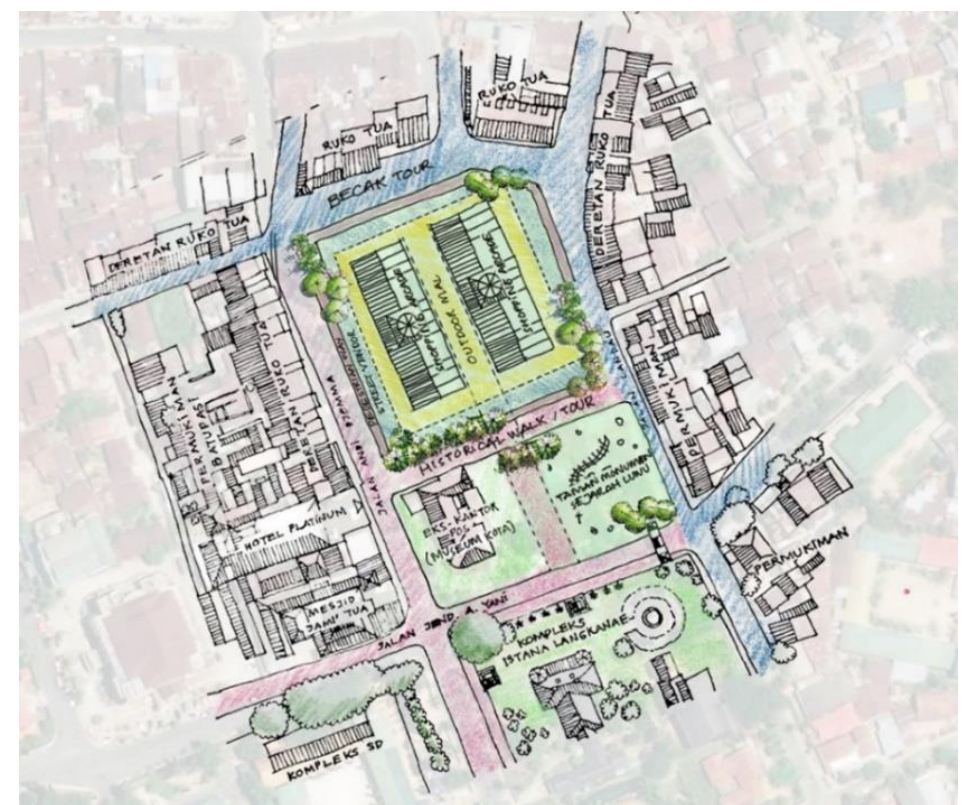

Gambar 4: Ilustrasi Site Kawasan Lalebbata

Sumber: hasil pemetaan \& ilustrasi penulis 2020 
Plaza di rencanakan untuk mampu mengakomodir berbagai aktifitas. Selain dapat berfungsi sebagai open space dan public space, juga dapat berfungsi sebagai alun-alun kota. Untuk fungsi komersil, pada site ini direncanakan sebagai pusak kuliner dan oleh-oleh Kota Palopo. Pada saat ini memang belum ada kawasan khusus sebagai pusat kuliner dan oleh-oleh. Fasilitas yang disediakan dapat berbagai macam seperti petak toko atau resto permanen atau hanya stan-stan gerobak untuk street food sehingga para pengunjung dapat memilih alternatif yang disukai. Selain itu disediakan pula fasilitas pedestrian untuk memudahkan pengunjung beraktifitas dengan nyaman. Dari hasil desain partisipatif yang telah dilakukan, disimpulkan beberapa elemen ruang terbuka yang dibutuhkan oleh masyarakat. Secara garis besar kebutuhan elemen-elemen ruang terbuka tersebut dapat dikelompokkan menjadi tiga kebutuhan utama yaitu: Taman Terbuka yang dilengkapi dengan attractive furniture, wisata sejarah dan budaya kota palopo, serta adanya pusat kuliner dan oleh-oleh. Ketiga kegiatan tersebut kemudian akan dielaborasi dalam suatu Kawasan. Bangunan utama berupa dua gedung komersil, dimana pada antara gedung tersebut direncanakan sebuah plaza memanjang yang dapat difungsikan sebagai outdoor resto atau cafe. Selain itu, plaza ini juga dapat digunakan untuk event-event tertentu seperti mini konser, acara launcing produk, dan event lainnya. Masing-masing gedung pada sisi dalam juga memiliki koridor yang direncanakan sebagai area komersil indoor. Di sekeliling bangunan utama, direncanakan pedestrian way, dan ruang-ruang publik untuk berbagai aktifitas sepert becak tour. Pada sisi luar terdapat ruko dan toko milik warga yang menunjang aktifitas di kawasan ini.

Berdasarkan hasil workshop making place yang telah dilakukan bersama masyarakat Kelurahan Batupasi, dibutuhkan areal komersial yang dapat dimanfaatkan masyarakat sebagai lapak atau tempat berjualan untuk kebutuhan ekonomi mereka.Sebagai wilayah tropis, perlu dipertimbangkan area-area indoor untuk mengakomodasi aktifitas pada saat siang hari. Bangunan utama direncanakan untuk mengakomodir kegiatan ini, baik itu kegiatan belanja, maupun kegiatan kuliner. Tiap gedung menyediakan petak-petak ruang yang dapat dimanfaatkan sebagai cafe, resto, toko pakaian atau souvenir, dan lain-lain.

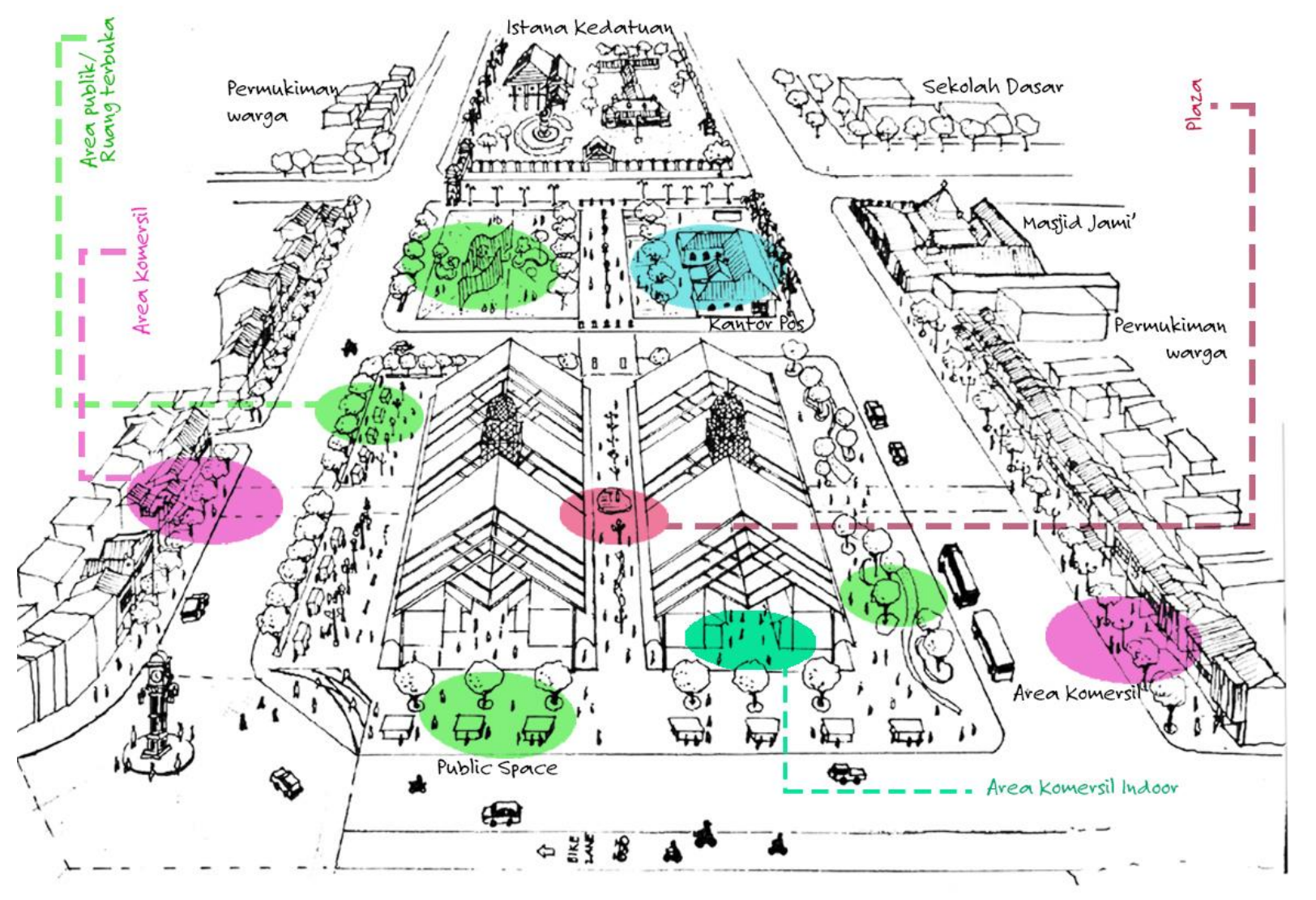

\section{Gambar 5: Ilustrasi Perspekrif Site Kawasan Lalebbata sumber: ilustrasi penulis, 2020}

Pada ruas Jalan Landau, bangunan ruko ex Pasar Lama direvitalisasi, dibuat lebih menarik secara visual dan tetap dipertahankan fungsinya sebagai bangunan komersil. Selain itu direncanakan pula ruang publik dan 
areal parkir untuk mengakomodasi pengunjung yang datang. Pada sisi yang lain merupakan bangunan milik warga yang juga dapat dimanfaatkan sebagai bangunan komersil sehingga dapat mendukung aktifitas komersil yang direncanakan. Fungsi-fungsi bangunan tersebut dapat diarahkan sebagai cafe, resto, toko sovenir dan oleh-oleh, hingga wisma atau penginapan. Selain itu pula disediakan sarana penunjang seperti kursi dan gazibo serta jalur pedestrian yang dilengkapi dengan penerangan agar pengunjung lebih nyaman dalam beraktifitas.

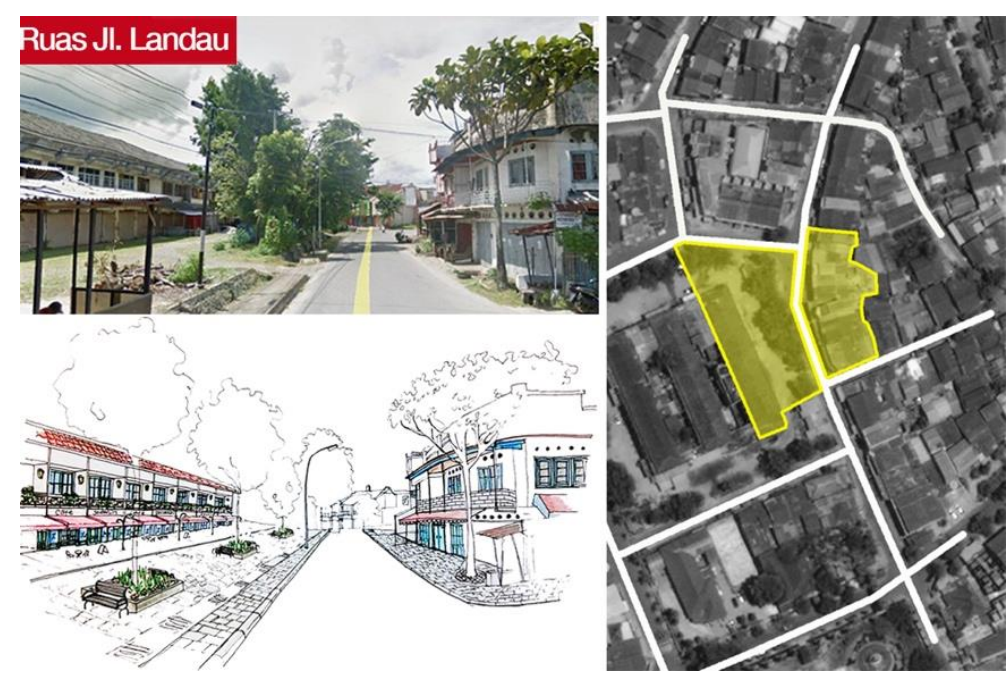

Gambar 6: Ilustrasi Konsep pengembangan Ruas Jalan Landau Sumber: hasil pemetaan dan ilustrasi penulis 2020

Sama halnya dengan ruas Jalan Landau, pada ruas Jl. A Djemma, bangunan ruko ex Pasar Lama juga direvitalisasi, dibuat lebih menarik secara visual dan tetap dipertahankan fungsinya sebagai bangunan komersil. Selain itu direncanakan pula ruang publik dan areal parkir untuk mengakomodasi pengunjung yang datang. Bangunan ruko milik warga yang sudah ada saat ini juga dapat menunjang fungsi kawasan, antara lain Warkop Pantilang, Warkop Kalindoro, beberapa toko dan bengkel. Beberapa ruko yang belum difungsikan, dapat dimanfaatkan sebagai bangunan komersil lain. Selain disediakan pedesterian dan RTH, juga disediakan lahan-lahan untuk pkl yang dapat dimanfaatkan warga untuk berjualan dan menawarkan jasa.

\section{Kesimpulan}

Konsep penataan dan perencanaan Kawasan Lalebbata sebagai kawasan heritage diperoleh dari berbagai tinjauan, baik itu tinjauan makro skala perkotaan, tinjauan kawasan Lalebbata, hingga tinjauan kebijakan pemerintah daerah Kota Palopo. Selain itu, proses pemetaan, identifikasi potensi dan masalah hingga proses perencanaan dilakukan dengan pendekatan yang partisipatif dan berusaha mengakomodir semua kebutuhan masyarakat yang tinggal dan berusaha di sekitar lokasi.

Konsep yang dihasilkan merupakan konsep perencanaan yang memanfaatkan bangunan-bangunan tua milik warga di sekitar lokasi dan memvitalkan eksistensi 3 bangunan cagar budaya yaitu Masjid Jami tua, Gedung kantor Pos dan istana Kedatuan Luwu yang ada di lokasi. Adapun pembangunan Gedung baru, tidak lepas dari konsepsi kawasan heritage, dan Palopo sebagai kota pusaka. Perencanaan ini diharapkan dapat menjadi rekomendasi kepada pemerintah untuk menata dan menghidupkan kembali Kawasan Lalebbata yang memiliki histori panjang terhadap Tana Luwu dan Kota Palopo pada khususnya.

\section{Referensi}

Bal'zannikova, E. M. (2014). Preserving urban objects of historicaland architectural heritage. Vestnik MGSU. https://doi.org/10.22227/1997-0935.2014.1.15-24

Chung, T. (2009). Valuing Heritage in Macau: On Contexts and Processes of Urban Conservation Introduction: The Multiplicity of Values in Heritage. Journal of Current Chinese Affairs.

Di Pietro Martinelli, P., Martelli, L., dan Scannagatta, M. (2016). Edutainment, cultural innovation and social inclusion. Fort360, a project for cultural heritage enhancement. DISEGNARECON.

Fisu, A. A., dan Marzaman, L. U. (2018). Pemetaan Partisipatif Kampung Pesisir Kelurahan Tallo Kota Makassar. To Maega | Jurnal Pengabdian Masyarakat. https://doi.org/10.35914/tomaega.v1i1.70

Kamel-Ahmed, E. (2015). What to conserve?: Heritage, memory, and management of meanings. Archnet- 
IJAR. https://doi.org/10.26687/archnet-ijar.v9i1.469

Lopez, Marcela., Kuc, M. (2010). MEDELLIN: "EL HUECO” AS A PUBLIC SPACE. Gestión y Ambiente, 12(1).

Luleva, A. (2015). Living with the world heritage. An ethnographic study of the ancient city of Nessebar, Bulgaria. Glasnik Etnografskog InstitutaBulletin de l'Institut Etnographique. https://doi.org/10.2298/gei15010191

Nóbrega, Maria de Lourdes Carneiro da Cunha., Duarte, C. (2010). Publicity and identity in the public space architecture. Urbe. Revista Brasileira de Gestão Urbana, 1(2), 223-234.

Nurhijrah, dan Kusuma, H. E. (2014). Koresponden antara Pilihan Ruang Publik dengan Kegiatan Pengunjungnya di Kota Makassar. In Prosiding Temu Ilmiah IPLBI 2014 (pp. B29-B34). Retrieved from https://temuilmiah.iplbi.or.id/koresponden-antara-pilihan-ruang-publik-dengan-kegiatanpengunjungnya-di-kota-makassar/

Oskam, J., dan Karijomedjo, G. (2015). Tourism in Tomorrow's World, 23-24 February 2014, Renaissance City Center Hotel Doha, Qatar. In Journal of Tourism Futures. https://doi.org/10.1108/JTF-12-20140024

Ramos, I. R. (2018). Urban corridors periferico sur and insurgentes sur and its impact on Mexico city cultural built heritage (1980-2018). Revista de Urbanismo. https://doi.org/10.5354/0717-5051.2018.50022

Sari, I. P. (2016). Implementasi Pembangunan Partisipatif ( Studi Kasus Di Kelurahan Andowia Kabupaten Konawe Utara). Jurnal Ekonomi (JE).

Wahab, L. A., Mohdhamdan, N. A., Lop, N. S., dan Kamar, I. F. M. (2016). Adaptive Re-Use Principles in Historic Hotel Buildings in Melaka and George Town. In MATEC Web of Conferences. https://doi.org/10.1051/matecconf/20166600030 